\title{
11 \\ SMUGGLING AS A LEGITIMATE ACTIVITY?
}

\section{The OPEC Boys as social bandits in Northern Uganda}

\author{
Kristof Titeca
}

\section{Introduction}

The term smuggling often brings strongly negative connotations, and is often associated with criminality and violence. For example, the Wikipedia page ${ }^{1}$ on smuggling mostly focusses on the trafficking of adults, children and wildlife. Indeed, in discussing these phenomena, the page highlights how smugglers use coercive tactics such as 'deception, fraud, intimidation, isolation, physical threats and use of force, debt bondage or even force-feeding drugs to control their victims. ${ }^{2}$ Are smugglers always associated with these negative connotations, though - in particular by the communities in which they are embedded?

In their influential edited volume on 'illicit flows,' Abraham and van Schendel (2005: 4) highlight the important differentiation between what states consider legitimate ('legal'), and what people involved in these practices consider to be legitimate or 'licit.' In other words, smuggling - an illegal activity - can also be considered legitimate by the wider population. This chapter further unpacks the ways in which smuggling can be considered legitimate by the local communities. It does so by relying on three concepts and sets of literature: (i) of smugglers as 'social bandits' (Hobsbawm 1959, 1981); (ii) of smuggling as a central concept in local social imaginaries (Taylor 2004; Grant 2014); and (iii) of smugglers as (un)civil society (Bayat 1997a, 1997b). These three concept intersect and overlap, but each highlight a particular aspect in explaining their legitimacy.

Empirically, these concepts will be illustrated by discussing smuggling activities in NorthWestern Uganda, in particular by focussing on the 'OPEC boys,' a group of smugglers active in the region, smuggling fuel into the country from the nearby Democratic Republic of Congo (DRC) and Southern Sudan. Importantly, these smuggling activities are considered socially legitimate in the wider region. In doing so, this case-study shows how smugglers can be seen as a politically, socially and economically legitimate: as actors who successfully emerge out of poverty and legitimately fend for themselves in a situation of state neglect. Moreover, they are also perceived to be acting in the interest of the population - for example by defending informal traders when threatened by the local government. 


\section{Social bandits, social imaginaries and uncivil society}

How do smugglers relate with the local population, and how are they understood by the latter? In order to answer this question - and understand the ways in which smuggling can be considered legitimate - it is useful to look outside of the smuggling literature stricto sensu. Strikingly similar questions have been asked by other sets of literature, discussing the (potential) legitimacy of illegal activities (which are broader than smuggling). The absolute starting point, and reference, in this literature is Eric Hobsbawm's concept of 'social banditry.'

Hobsbawm first coined the term social bandits in his 1959 book Primitive Rebels, in which he discussed 'primitive' or 'archaic' forms of organized social protest. One of the these was the 'social bandit,' most famously known by its archetype such as Robin Hood in England or Diego Corrientes in Andalusia: bandits who are regarded as the champion of the poor, protected and idealized by them (Hobsbawm 1959: 13). The idea was further developed in his book Bandits, first published in 1969, and consequently republished in a series of other editions (such as Hobsbawm 1981).

While social bandits are regarded as criminals by the state, the population regards them as 'heroes, as champions, avengers, fighters for justice, perhaps even leaders of liberation, and in any case as men to be admired, helped and supported' (Hobsbawm 1981: 17). This is what makes the bandits 'social,' the link they have with the general population. In this situation, the bandits are not only seen as the population's champions, they are also idealised, and turned into a 'myth' or a 'symbol' (Hobsbawm 1959: 13; 1981: 127). They are associated with 'freedom, heroism, and the dream of justice' (Hobsbawm 1981: 132). Key is their invulnerability to authority, and their championing of the weak, oppressed and cheated. In doing so, social bandits aim to re-establish the social order to how it 'should be:' rights must be wronged and corrected, and cases of injustice must be avenged - particularly in relations between the rich and the poor, or the strong and the weak. Social banditry is therefore a form of self-help to correct perceived wrongs and cases of injustice (Hobsbawm 1981: 26).

Those most prone to joining social banditry are those in a particular social position: male youth between puberty and marriage - when they do not have family responsibilities yet; or those who are not fully integrated into society yet, and are easily drawn into marginality or outlawry. They are 'marginals, soldiers, deserters and ex-servicemen' and are 'natural material for banditry' (Hobsbawm 1981: 31-34).

According to Hobsbawm, social banditry is something of the past, which is no longer possible in (post) capitalist societies - the phenomenon being a product of traditional peasant societies (Hobsbawm 1981: 19-24). Nevertheless, the social bandits idea has been applied to contemporary cases such as the kidnapping of oil workers (Oriola 2013); street leaders in Seoul (Mobrand 2016); urban violence in Trinidad (Pawelz 2018); TV series (Sartore 2017); Colombian Bandits (Rehm 2016), and so on.

The 'social banditry' concept is also useful to look at the ways smuggling is understood by various actors. Similar to social bandits, the idea of smuggling has been described as a 'weapon of the weak' - an economic and political act of resistance against colonial borders, against an exploitative state, and oppressive economic policies (Azarya and Chazan 1987; Titeca 2012). Smuggling constitutes an act of resistance and redistribution, acting in the defense of marginalized sections of society, the 'powerless' (Meagher 2003). This for example was influentially shown by Janet MacGaffey (1987), who showed how the second economy in Zaire was also a political option, allowing the population to 'fend for itself' in the light of a state which was both absent and oppressive. As argued above by Abraham and van Schendel (2005), it is necessary to 
look beyond official statist discourses on smuggling (which are part of particular power configurations).

These ideas- of smuggling as socially and politically 'legitimate' - do have significant overlap with the concept of social banditry. Yet, what is lacking in these perspectives is an explicit focus on particular actors - the social bandits themselves: how does the 'myth'-making around them happen, and how do they relate with the surrounding community?

In better understanding this, two further sets of literature are useful. First, underdeveloped in the idea of social bandits is that these are formed through profoundly moral understandings of what constitutes 'good' and 'bad.'

Helpful here is the concept of 'social imaginaries,' which constitute a 'collective moral orientation (Grant 2014: 413); a 'largely unstructured and inarticulate understanding of our whole situation, within which particular features of our world show up for us in the sense they have' (Taylor 2004: 25). Social imaginaries are not only a passive 'background' to particular situation, they also offer 'detailed articulations of our own personal circumstances' (Grant 2014: 412). In doing so, they are the common understanding, a collective imagining, which allow collective practices to happen, and offer a 'widely shared sense of legitimacy' for these (political, social and economic) practices (Taylor 2002: 106; Grant 2014: 411). In other words, they explain practices - they offer a purpose and significance - and in doing so make these practices possible (Grant 2014: 412). These social imaginaries are widely shared among the population: they are "carried in images, stories and legends" (Taylor 2002: 106), and are further magnified, but also transformed, through social practices. In other words, social imaginaries are the background against which social bandits occur -the moral basis on which norms of legitimate behavior are evaluated and acted upon. To come back to van Schendel and Abraham's reference from the intro: illegal actions such as smuggling can be considered legitimate because they tap into particular social imaginaries - something which will be explored in the case study.

Second, further deepening the understanding of the above issues is the literature on 'uncivil society,' and in particular the work of Ayad Bayat (1997a, 1997b). Whereas Hobsbawm's social bandits clearly focusses on resistance in rural areas (Hobsbawm 1959: 23), Bayat's idea of uncivil society is very much focused on similar processes urban areas. Ayad Bayat's work argues how debates on 'civil society,' should not only focus on conventional associations, but also, or even particularly on what he calls 'uninstitutionalised and hybrid social activities which have dominated urban politics in many developing countries' (Bayat 1997a: 55). In doing so, he focusses on the urban poor, which largely live in informality, and are weary of formal procedures attempting to regulate their lives and the discipline which the state tries to enforce on their daily lives - such as formal bills and taxes (Bayat 1997a, 1997b). While they don't have institutional power, they are able to take direct action. These actions are more than 'Scottian' forms of resistance, which are hidden, individual and defensive. Instead, they are also offensive, involving collective, open and highly visible actions (Bayat 1997a: 56, 1997b: 4-7).

Autonomy and redistribution are key here, and are key aspects of the uncivil society: acting autonomously from the state, and in doing so obtaining public goods such as illegal land, or shelter, which are unable to be attained through legal and institutional mechanisms (Bayat 1997a: 59-61). In these actions, particular sites - such as the street or illegal land - serve as the main 'locus of collective expression' for those who lack an institutional setting to express their voice (Bayat 1997a: 63).

In the next section, we apply these perspectives to smuggling in Northwestern Uganda, in particular by looking at the OPEC boys. 


\section{Smuggling in Northwestern Uganda: the OPEC boys}

The West Nile region is located in north-western Uganda, and borders the Democratic Republic of Congo (DRC) and Southern Sudan. The region has characteristics similar to many other borderlands: borders which were introduced during colonial times, separating ethnic groups living on both sides of the borders; and located on the peripheries of their respective national states, with limited possibilities for economic development. In this context, smuggling is a popular source of livelihood, providing not only a livelihood for traders and their families, but also by supplying goods (food and non-food). Its importance therefore transcends the local, by not only providing goods for the border towns, but also at a national and regional level - on the different sides of the border. Studies from the Bank of Uganda for example show how this trade has strongly intensified, from USD 143.2 million in 2010 to USD 269.8 million in $2018 .^{3}$

The most visible and prominent actor within this field are the 'OPEC boys,' a group of fuel smugglers. From the mid-1980s onwards, the OPEC boys were selling smuggled fuel in jerrycans on street-corners in Arua, and in the wider region: there was a general shortage of petrol stations in the area, and their fuel was cheaper. The OPEC boys got their smuggled fuel in different ways: some smuggled it themselves from Congo, others used 'transporters,' which mostly were young(er) boys on bicycles, smuggling the fuel across the border on 'panya roads' (smuggler roads), avoiding security officials. Others bought their fuel from truck-drivers, who equally smuggled their fuel into Uganda (Titeca 2006; Lecoutere and Titeca 2007). ${ }^{4}$

The OPEC boys were the most important supplier of fuel in the area until the late 2000s. Around this time, the increased number of fuel stations, and the changing tax regime in the DR Congo pushed many of them out of business. While they still exist, their activities are less prominent; contrary to earlier times, they no longer are present on (almost) every corner of the major urban centres in the region.

Throughout their existence, their smuggling activities were generally tolerated by the state authorities; while occasional confiscations would take place, these were rather rare, and the smuggled fuel was sold openly. Why was this the case? In this section, we will unpack their activities, by drawing on the above conceptual toolbox. I start by showing how they are a central part of the social imaginary, to then show how they can be considered social bandits, and a central part of uncivil society.

Field research among the OPEC boys was carried out from 2004 onwards, in Arua. The most intense period of field research was between 2004 and 2010, first as part of my $\mathrm{PhD}$ research, and later as part of my postdoctoral work, during which period I spent around a year in the town (Titeca 2006, 2008, 2012; Titeca et al. 2011). In the years after that, research was less intensive, but I kept following up on, and interacting with these actors (Titeca 2018a, 2018b). The main research method was semi- or unstructured interviews and non-participant observation, not only with the OPEC boys, but also with other actors such as (informal) traders, civil society actors, local government representatives, customs officials, and a variety of actors active in the smuggling business (fixers, transporters, and so on).

Before we discuss the OPEC boys, it is important to discuss the 'background' - the way in which smuggling is understood in the social imaginary in the region. After doing so, we are better able to understand the role of the OPEC boys as social bandits and uncivil society.

\section{Smuggling as an important social imaginary in West Nile}

In the region of West Nile, smuggling is very much looked at as a legitimate activity. A number of reasons account for this. First, smuggling in West Nile has long historical roots (Meagher 
1990; Titeca 2009). When the colonial powers introduced colonial borders, these did not stop the interaction among ethnic groups. While members of the same ethnic group were now living on different sides of the (colonial) borders, and hence became subject to state regulation, untaxed trade - smuggling - continued being considered legitimate (Titeca and De Herdt 2010). Second, smuggling has always been seen as a legitimate way of survival in circumstances in which the population felt marginalized at best, and oppressed at worst. For example, during the successive wars and rebellions affecting the region, many people fled into neighboring (southern) Sudan and Zaire. Smuggling constituted an important livelihood for many during these times (particularly in the late 1970s and early 1980s). Moreover, smuggling acquired an explicitly political meaning when President Museveni came to power. The West Nile region feels marginalized by the Museveni regime. They feel that - contrary to earlier regimes - they are not allowed into positions of power, which (amongst other things) translates itself in limited services and infrastructure (Titeca and De Herdt 2010). This context gave rise to a number of rebel groups which were translating these grievances (Leopold 2005: 46). Smuggling has to be understood in this context: as a way of making ends meet, in circumstances beyond their control - war and displacement, or a regime which is marginalizing them. The following quotes are an illustration of these feelings:

Smuggling really is the food of the people! Us, women, we have no jobs here. The only thing we can do is to get a small profit out of smuggling. And what we get across, really is for the family! ${ }^{5}$

According to security officers, this argument is for example used upon arrest 'When we arrest them, smugglers often say: but I'm not an idler, I'm a smuggler! What else do you want me to do? How should I find something to eat? ${ }^{6}$

In sum, smuggling acts as an important social imaginary in the West Nile region: In the light of a lack of limited socio-economic opportunities, smuggling is regarded as a legitimate employment.

Adding to this social imaginary are different sets of stories and practices which are widely shared and recounted, and which further feed into the understanding that smuggling is the only way to survive. Among the OPEC boys, many share how smuggling was a way to finance their (secondary) school or university. Inversely, a number of unemployed university graduates are now working as OPEC boys.

Particularly important is the story of the 'Arua boys,' which can be considered as the predecessors to the OPEC boys. In brief, these are smugglers from - as their name suggests - Arua town, which emerged in the 1970s. They emerged in a time of conflict and displacement, and primarily engaged themselves in the trade of gold. They were able to smuggle it from Zaire, and sell it at a high profit in Kampala. They were known for their flashy clothes and extravagant lifestyles. As recounted by a market trader:

The Arua boys, they used to dress smartly. They would have a tie. Or they would dress in jeans. American jeans were very popular! And they would have a saloon car, mostly a Sunny. If not a car, a motorcycle: Honda or Yamaha. And they would play loud Lingala Music. They used to be very extravagant. They were spending lots of money - because they were very rich, because of the gold trade. They were powerful financially. The Blue Room lodge [in Kampala] was famous these days. But they wouldn't sleep there! They would just go in the morning with the plane, and come back in the evening. ${ }^{7}$ 
Similar variations were told by many other actors, but they are all variations on the above. Importantly, many of them have transformed over the years into influential businessmen in the region, which are still active in smuggling, but have expanded their activities, including real estate, transport, and so on.

Magnified through these actors and stories, smuggling is seen as a local version of the 'American dream,' the most important form of social mobility, a rags-to-riches, from-zero-tohero story, present in the wider social imaginary of the border population in West Nile. As one trader summarized this: "From hero to zero: it's not an American dream, it's the Arua dream lived by the OPEC boys!". ${ }^{8}$ An anecdotal, but telling, example of this is how a youngster explained an elaborated movie scenario about the Arua boys, portraying the Arua boys, as James Bond-style superheroes, going on adventures in Congo, smuggling goods across the border, and fighting villains of the custom authorities and the Ugandan government. ${ }^{9}$ A young Arua cartoonist had a similar idea, and developed a movie poster along these lines, containing the same references - as depicted below (Figure 11.1).

Striking here are the Arua, and OPEC boys, posing as successful personae, in aesthetics referring to successful US gangsta-rappers: cool clothes and names, and an even cooler car. The 'Life is a beautiful struggle' quote refers to the 'from-zero-to-hero' mentality with which they are ascribed - being successful in the light of difficult circumstances. The OPEC boys need to be understood in this context: similar to the Arua boys, their activities are seen as way in which the marginalised population is able to survive.

In sum, smuggling is a clear social imaginary, a collective moral orientation (Grant 2014) for the West Nile region, offering a 'widely shared sense of legitimacy' (Taylor 2002: 106; Grant 2014: 411) to the activity - for those participating it, and for the wider community. This is shared through stories, which center around specific actors - such as for example the ways in which the Arua boys and the OPEC boys are acting, and narrated about. It also is reflected in the day-to-day usage of the term 'smuggling.' It is used literally, without negative connotations. In the words of a local analyst 'different from the way many others use it. It is seen in a positive light, as a survival strategy. ${ }^{10}$

In the next sections, I will explain how the OPEC boys can be considered as social bandits, and 'uncivil society.'

\section{The OPEC boys as social bandits}

The historical roots of the OPEC boys can also found in a period of conflict and displacement. Much of the population was forced out of West Nile after the overthrow of the Amin regime (as Amin hailed from this region and had an important power base in it). People settled in Congo and Sudan in late 1979 and the early 1980s. During this time, a number of exiled young men tried gain an income by smuggling fuel. They did not stop doing so upon return to Uganda, and they started an organization which came to be known as the 'OPEC boys.' Many other young men returning to their home areas, with no education or assets, were easily drawn into his fuel business. They started attracting members from neighboring districts in West-Nile (such as Nebbi or Moyo), to which the OPEC boys from Arua supplied fuel.

The OPEC boys were considered an important social-economic force, in a number of ways. First, and in line with the above, they were an important source of employment for young men. As one OPEC boy argued: "All of us are looking for survival! This is a marginalized area, and this [smuggling] is our only way of doing this. ${ }^{, 11}$ In other words, the OPEC boys are very much a product of the above described context producing this particular imaginary, in which 

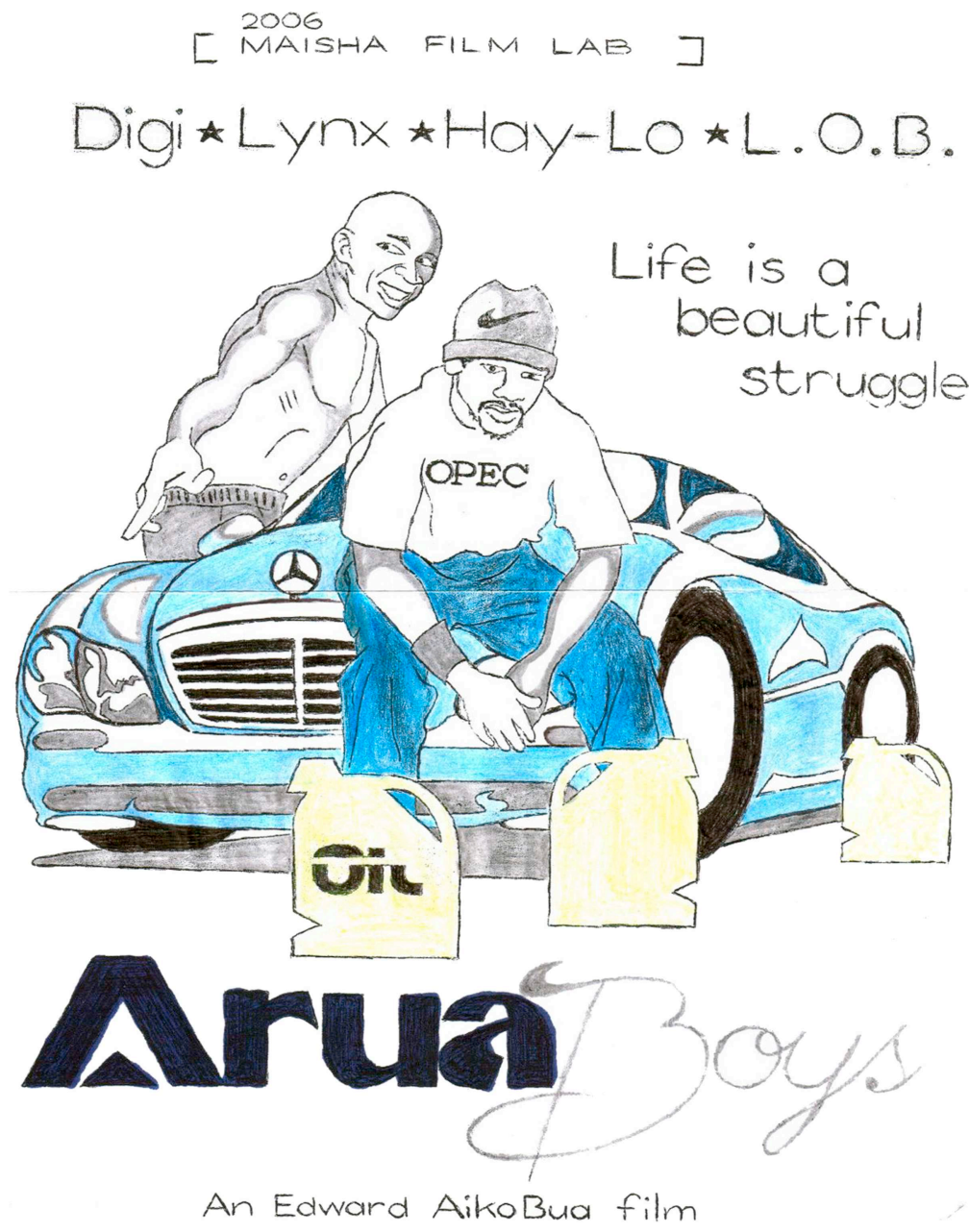

Figure 11.1 Poster of a (fictional) film on the Arua Boys smugglers'.

Source: Edward Aikobua

smuggling is considered a source of livelihood, and legitimate. This would also be reflected in its relation with the local population - and the actions of the latter, which generally would support the OPEC boys in several ways. They would, for example, warn the smugglers in case security agencies were approaching to confiscate fuel, or if something would go wrong.

The OPEC boys also tapped into this imaginary in a different way: they were not only providing employment for a particularly marginalized, and potentially dangerous group, i.e., former rebels and security officers. In the first ten years of group, it was estimated that $40 \%$ of the Opec Boys were ex-rebels from the many rebel movements which had been active in the area (UNRF, UNRFII, WNBF, FUNA, LRA) (Gersony 1997), while others were defected government soldiers (the Ugandan government army UPDF or the Local Defense Units, in which the government armed civilians against these rebel forces). After receiving amnesty, the ex-rebels, often without education, land or other assets, were easily drawn into the smuggling business. 
This adds another layer to the OPEC boys: they were not only providing a source of survival, they also were providing employment to, and absorbing, a potentially dangerous group, hence providing stability. Certainly in the beginning of the movement, it seemed as this big group of low-skilled, landless, young men had two attractive choices: joining any of the rebel groups in the area ${ }^{12}$ or joining the informal economy by becoming an OPEC boy. As the Mayor of Arua town stated: 'These Boys can be tough; they are former soldiers and rebels. They are dangerous and could go back to the bush if not treated carefully., ${ }^{13}$ With few or no assets available, there would be few opportunity costs for the OPEC boys to join a rebellion. Moreover, many ex-combatants have not handed over their weapons to the authorities (CERFORD 2002), in an area in which decades of armed conflict already resulted in an abundance of available light weapons.

In this situation, the OPEC boys very much fed into the social imaginary lined out above: they were seen as a source of survival and employment, which therefore was a legitimate source of livelihood. Interestingly, the agenda of the rebel groups which had been, and were active in the region also drew on this imagery of a region which was neglected by the state, and was fighting to undo this marginalization through violent means. Similarly, smuggling was perceived as a way to protest this marginalization, but in providing more stability.

The above shows how the OPEC boys very much fulfil the idea of social bandits: they are seen as 'fighters for justice' (Hobsbawm 1981: 17), finding an income and creating development in a region which feels abandoned by the national government. Similar to Hobsbawm's ideas on social banditry, their activities are seen as highly legitimate, and as invulnerable to state authority - as they are able to conduct their activities more or less undisturbed. It also is a specific demographic which was part of Hobsbawm's social bandits: young, unemployed men, among which many ex-rebels - which, as also Hobsbawm saw it - were 'natural material for banditry' (Hobsbawm 1981: 31-34).

A last idea which deserves further illustration is the 'social' aspect of social bandits: the ways in which smugglers - in this case, the OPEC boys - are linked with the general population. Bayat's (1997a, b) ideas on uncivil society are particularly useful in doing so.

\section{The OPEC boys as 'uncivil society'}

The OPEC boys would use their power to the defense of actors within the urban informal sector, such as market vendors or boys working in the transport sector (motorcycle taxi drivers and others). They would use their power to mediate with the government, or block particular governmental initiatives. Many examples illustrate how they would act as the (above described) 'uncivil society.' For example, they intervened when law enforcement officers confiscated goods from roadside sellers refusing to pay tax (by taking back these goods and creating a riot). They intervened in instances where the urban authorities wanted to remove streetside kiosks, by blocking the roads, and staging protests - ultimately stopping this removal. They also intervened on occasions when the local authorities tried to remove women who were cooking in the different markets in town (as they were accused of contributing to the spread of diseases such as cholera). When the municipal authorities came to remove the women by force, the OPEC boys intervened and made this intervention impossible. They also negotiated with the municipal authorities to find a solution, in which the women were allowed to stay in the end.

While a number of factors contributed to this influence of the OPEC boys (such as the fact that they were particularly well-organized - in sub-groups, with a general leadership), it particularly was their potentially 'rebellious' character which played an important role in this. In the words of an OPEC boy 'they come to us because we are aggressive, we don't fear anyone 
and are organized.' Moreover, through their close contact and respect by other urban informal groups, they can easily organize protest and chaos within town.

Interrelated with this, the OPEC boys were considered 'political kingmakers.' During a number of consequent elections, the OPEC boys actively campaigned for opposition candidates - all of which won the elections. Out of their 'respected' status, they have a strong impact on public opinion. Politicians confirm how they can easily spread messages about which politicians deserve popular support, or inversely, about which politician has been doing a bad job. They also act as a campaign force - driving in the rallies of the politicians. In return, politicians do provide several services to the OPEC boys. They have been linking them with donors or have helped them to write project proposals through which the OPEC boys have accessed additional funding, for example to start a savings and credit association. They also provide them with material assistance; many OPEC boys consult politicians in case of financial problems such as sickness or problems with school fees for their children.

It is important not to romanticize the activities of the OPEC boys, in particular their use of violence. This was not only a passive background, i.e., a threat constituted by their existence as former rebels; it also played an active role. This was, for example, the case during riots against the governmental authorities, or when intimidating political opponents during electoral periods. Most visibly, there also were instances in which it was used against informers: those caught with, or suspected of, leaking to the customs agents were beaten up seriously. In other words, the flip-side of a social imaginary legitimizing smuggling is that leaking this to the government is considered illegitimate. The OPEC boys did act upon this, often through the actual use of violence.

In sum, the OPEC boys have clear links with the population (the 'social' in social bandits), by whom they are seen as fighters for social justice. In doing so, they function very much how Bayat (1997a, b) described 'uncivil society,' operating through direct, open and visible actions, using the city's streets as their main locus to resist enforced state discipline, such as taxation or other forms regulation. Their actions are not institutionalized, but ad hoc, and in the interests of the urban poor.

Lastly, it is worth mentioning that since around 2010, the influence of the OPEC boys has reduced significantly. It wasn't only that their economic significance declined. Through changing taxation policies, and an increasing number of petrol stations, smuggling fuel became less attractive, leading to a reduced number of OPEC boys. Also their political and social importance reduced. Before, they had quite a tight structure, with an overall leadership including a charismatic leader, Kaku - and sub-divisions, which were based on street-corners (Titeca 2006). This allowed them to be tapped into the broader urban informal economy, as well as to act swiftly for social and political reasons - as illustrated above. Similar to smuggling activities worldwide, they had an ambiguous relation with government officials. While they had to fear confiscation by customs officials, they also collaborated with government officials in a number of ways. Individual officials (civil servants and/or politicians) would participate in smuggling activities (e.g., through financing it) and/or protect these activities, for example, against the actions of customs officials. Army officials played a particular role in this (again mirroring the important role of security officials in smuggling activities worldwide). After 2010, their reduced economic role also had a cascade effect in these other fields: they no longer had a tight structure or a charismatic leader, with a lesser social and political role - being reduced to one actor in the urban informal economy, rather than being the leading actor. 


\section{Conclusions}

For the law, anyone belonging to a group of men who attack and rob with violence is a bandit, from those who snatch payrolls at an urban street corner to organized insurgents or guerrillas who happen not to be officially recognized as such. Historians and sociologists cannot use so crude a definition. In this book we shall be dealing only with some kinds of robbers, namely those who are not regarded as simple criminals by public opinion. (Hobsbawm 1981: 17; emphasis in original)

This is how Hobsbawm's book Bandits starts: by introducing an important difference between how criminality and (il)legitimacy is looked at by the state, and how it is perceived by local conventions. While Hobsbawm brings in petty thieves and insurgents as examples of social bandits, this chapter aimed to show smugglers also can be added to this: while formally, smuggling is illegal and criminal, it is not regarded as such by local conventions. In unpacking this idea, the chapter first showed the importance of social imaginaries, which are more than 'myth-making:' they lay out importance normative associations, constituting the 'background' in which actions are evaluated, but also authorising concrete actions. It showed how smuggling constitutes a rags-to-riches, from-zero-to-hero story in the region, inspiring many dreams of what is considered one of the few (or even only) form(s) of socio-economic mobility.

The chapter then sets out to show how smuggling constitutes a form of social banditry, showing how smugglers - and in particular the OPEC boys - have important links with the local population: their actions are defending the local population in different ways. They are an important form of local employment, and they often intervene to the advantage of the poor. Different from Hobsbawm's idea of social banditry, the OPEC boys largely operate in urban contexts. Further helping to unpack their 'social' character is Bayat's (1997a, 1997b) idea of 'uncivil society:' they can be considered an unconventional, uninstitutionalised, form of civil society. Through ad hoc, direct and sporadic action, they are an important form of collective action representing the interests of those working in the informal sector, against a state which is seen as neglecting the population at best, and harassing and attacking the population at worst.

A critique on Hobsbawm's idea of social bandits was that he was not relying as much on the actual deeds of the bandits or on what the relevant population thought them to be, but rather on how these were reproduced in myths (Chandler 1978: 241). In doing so, he was accused of exaggerating the link between peasants and bandits - the very link which makes banditry 'social' (Slatta 2004: 29). Also for the OPEC boys, attention should be given not to romanticise their actions. While they definitely performed these social functions, also their 'darker' side should be taken seriously: their passive and active use of the threat of violence.

In sum, smuggling is not only something which is perceived as something negative, both in the functional and normative sense, i.e., as respectively an aberration and contravention of state rules, and something 'bad,' involving deception, fraud and intimidation - as the Wikipedia definition suggests. As this chapter has shown, smuggling can carry a very different meaning in local social contexts, where it can be perceived as a legitimate activity, and play a muchrespected social role.

The importance of these findings is not limited to West Nile, or the OPEC boys. It illustrates the importance of taking local understandings of smuggling into account. This does not only help us understand the persistence of smuggling and its widespread nature, but also shows its profoundly social character - in the sense which Hobsbawm suggested: by having close links with the population. Smuggling should therefore be looked at as more than a strictly economic activity, but as a social, and also a political activity: as was demonstrated above, in local social 
imaginaries, it is seen as an act of resistance, a way to fend for oneself in the light of an absent and oppressive government. Similar to bandits, smugglers such as the OPEC boys can be considered a 'symbol' (Hobsbawm 1981: 127) of this resistance.

Lastly, while further research is needed on the exact conditions in which smuggling can be considered socially legitimate, this chapter brings a number of important pointers. In particular, it highlights the importance of the relation between smugglers and the broader population, and (interrelated with this) the relation between smugglers and the national state. Do smugglers defend the broader poor and/or offer opportunities for this latter group? Do they rather serve as an instrument for elites entrenching existing structural power inequalities? In other words, and linking with earlier (and abovementioned) debates on smuggling: does smuggling constitute a 'weapon of the weak' or a 'weapon of the strong' (Titeca 2012)? It is unlikely that in the latter case, smuggling will be considered socially legitimate - instead being perceived as a manifestation of the criminalization of the state, or a general warlord economy. In other words, understandings and analyses of the nature of smuggling - and in particular on its relation with the local population - are not only conceptual discussions, but also have important implications on the ways in which they are locally perceived and seen as socially legitimate.

\section{Notes}

1 Wikipedia, 'Smuggling,' https://en.wikipedia.org/wiki/Smuggling, consulted on 5 September 2020.

2 Wikipedia, 'Smuggling,' https://en.wikipedia.org/wiki/Smuggling, consulted on 5 September 2020.

3 The Bank of Uganda and Uganda Bureau of Statistics keep statistics on Informal Cross-Border Trade or smuggling. As explained elsewhere (Titeca 2020), these figures remain an underestimation.

4 Concretely, the trucks come from Kenya (Mombasa), and are in theory destined for Congo or (South) Sudan: as they are on transit, they don't have to pay taxes. Yet, the trucks either do not reach Congo or (South Sudan), or the fuel is immediately smuggled back into Uganda.

5 Interview women smuggler, 3 February 2010.

6 Interview security officer, 9 April 2007.

7 Interview market trader, 11 April 2007

8 Interview, trader, Arua, 14 October 2008.

9 Interview, 15 October 2008, Arua.

10 Interview analyst, 15 April 2021.

11 Interview OPEC boy, 1 February 2010.

12 The West Nile region has a long history of rebel groups (Leopold 2005); and although the rebel groups have ceased to exist, these ex-rebels still have deep-rooted feelings of marginalization. A factor which is enhanced by the fact that the government is not fulfilling its promises on the amnesty (in particular for the WNBF).

13 Interview Mayor Arua 11-04-07. This view is confirmed by various other actors, such as the URA Customs Enforcement Unit officer 21-11-05, sub-county chairpersons 01-05-07, local trader 11-04-07 and so on (cf. Titeca, 2006).

\section{Bibliography}

Abraham, I. and W. van Schendel (2005) 'Introduction: the making of illicitness,' in I. Abraham and W. van Schendel (eds), Illicit Flows and Criminal Things. Bloomington and Indianapolis: Indiana University Press, 1-37.

Azarya, V. and N. Chazan (1987) 'Disengagement from the state in Africa: reflections on the experience of Ghana and Guinea,' Comparative Studies in Society and History, 29: 106-131.

Bayat, A. (1997a) 'Un-civil society: The politics of the 'informal people,' Third World Quarterly, 18(1): 53-72.

Bayat, A. (1997b) Street Politics. Poor People's Movements in Iran. New York: Columbia University Press. 


\section{Smuggling as a legitimate activity?}

Blok, A. (1972) 'The peasant and the brigand: social banditry reconsidered,' Comparative Studies in Society and History, 14(4).

CERFORD (2002) 'Small Arms Research in the Border Areas of Uganda. A case study of West Nile districts of Arua, Yumbe, Moyo and Nebbi.' Arua: CERFORD. Unpublished.

Chandler, B.J. (1978) The Bandit King: Lampiao of Brazil. College Station, TX: Texas A\&M Press.

Gersony, R. (1997) 'The Anguish of Northern Uganda,' report submitted to the US Embassy, Kampala and USAID mission, Kampala.

Grant, J. (2014) 'On the critique of political imaginaries,' European Journal of Political Theory, 13(4): 408-426.

Hobsbawm, E.J. (1959) Primitive Rebels. Manchester: The University Press.

Hobsbawm, E.J. (1981) Bandits (revised edition). New York: Pantheon Books.

Kelty, C. (2008) 'Geeks, social imaginaries, and recursive publics,' Cultural Anthropology, 20(2): 185-214.

Lecoutere, E. and K. Titeca (2007) 'The OPEC boys and the political economy of smuggling in northern Uganda.' Household in Conflict Network Working Paper, 36.

Leopold, M. (2005) Inside West Nile. Oxford: James Currey.

MacGaffey, J. (1987) Entrepreneurs and Parasites: The Struggle for indigenous capitalism in Zaire. Cambridge: Cambridge University Press.

Meagher, K. (1990) 'The hidden economy: informal and parallel trade in Northwestern Uganda,' Review of African Political Economy, 17(4): 64-83.

Meagher, K. (2003) 'A back door to globalisation? Structural adjustment, globalisation and transborder trade in West Africa,' Review of African Political Economy, 30(95): 57-75.

Mobrand, E. (2016) 'The street leaders of Seoul and the foundations of the South Korean Political Order,' Modern Asian Studies, 50(2): 636-674.

Oriola, T.B. (2013) Criminal Resistance? The Politics of Kidnapping Oil Workers. New York: Routledge.

Pawelz, J. (2018) 'Hobsbawm in Trinidad: understanding contemporary modalities of urban violence,' Conflict, Securityand Development, 18(5): 409-432.

Rehm, L. (2016) 'Doing politics with violent means: the threshold bandits of the Violencia Tardia in Tolima (Colombia),' Chronica Mundi, 11(1): 198-230.

Sartore, M. (2017) 'Robin Hood goes to Neptune: the collective social bandit in Veronica Mars,' Studies in Popular Culture, 40(1): 53-77.

Slatta, R.W. (2004) 'Eric J. Hobsbawm's social bandit: a critique and revision,' Contracorriente, A Journal on Social History and Literature in Latin America, 1(2): 22-30.

Taylor, C. (2002) 'Modern Social Imaginaries,' Public Culture, 14(1): 91-124.

Taylor, C. (2004) Modern Social Imaginaries. Durham and London: Duke University Press.

Titeca, K. (2006) 'Les OPEC boys en Ouganda, trafiquants de pétrole et acteurs politiques (The OPEC Boys in Uganda: petrol smugglers and political actors),' Politique Africaine, (103): 143-159.

Titeca, K. (2009) 'The Changing Cross-border Trade Dynamics Between North-western Uganda, Northeastern Congo and Southern Sudan,' Crisis States Working Paper 63 Series 2, London: London School of Economics and Political Science, Crisis States Research Centre.

Titeca, K. (2012) 'Tycoons and contraband: informal cross-border trade in West Nile, north-western Uganda,' Journal of Eastern African Studies, 6(1): 47-63.

Titeca, K., T. De Herdt (2010) 'Regulation, cross-border trade and practical norms in West Nile, northwestern Uganda,' Africa, 80(4): 573-594.

Titeca, K., L. Joossens, M. Raw (2011) 'Cigarette smuggling and war economies in central and eastern Africa,' Tobacco Control, 20(3): 226-232.

Titeca, K. (2018a) 'Illegal ivory trade as transnational organized crime? An empirical study into ivory traders in Uganda,' British Journal of Criminology, Online first.

Titeca, K. (2018b) 'Understanding the illegal ivory trade and traders: evidence from Uganda,' International Affairs, 94(5): 1077-1099.

Titeca, K. (2020) 'Informal cross-border trade along the Uganda-DRC Border,' Policy Brief Series No 2, Nairobi: UNDP United Nations Development Programme. 